\title{
Examination of the Restructured Turkish Teaching Undergraduate Program
}

\author{
Mehmet Alver ${ }^{1} \&$ Edanur Aydın ${ }^{2}$ \\ ${ }^{1}$ Faculty of Education, Giresun University, Giresun, Turkey \\ ${ }^{2}$ Institute of Social Sciences, Giresun University, Giresun, Turkey \\ Correspondence: Mehmet Alver, Faculty of Education, Giresun University, Giresun, Turkey.
}

Received: July 11, 2019 Accepted: August 22, $2019 \quad$ Online Published: October 25, 2019

doi:10.5539/ies.v12n11p125 URL: https://doi.org/10.5539/ies.v12n11p125

\begin{abstract}
In the 21 st century, dizzying rapid changes and innovations in science, technology, social life, learning and teaching approaches have redefined the characteristics of the type of human targeted to rise. The duty of training individuals with these qualifications falls to the teachers after the family. The training of teachers, who are the vital point of the education system, plays a key role in educating individuals with targeted qualifications. When considering history of training of teachers in Turkey, the existence of deep-rooted history is clear. As teacher training institutions change over time, it is seen that teacher training programs are renewed or updated parallel to the change. As a final, arrangements are made in 25 of teachers training undergraduate program to be applied in 2018-2019 academic year. One of these programs is the Turkish Teaching Undergraduate Program. The aim of this study is to examine the restructured Turkish Teaching Undergraduate Program in comparison with the previous Turkish Teaching Undergraduate Program in various aspects. The study is a descriptive study in screening model. The study group of the research consists of the 2006-2007 Turkish Teaching Undergraduate Program and the Turkish Teaching Undergraduate Program implemented in the 2018-2019 academic year. The data of the study was collected by qualitative research techniques through document analysis. The descriptive analysis technique was used in the analysis of the study data and the data collected about the problem of the research were tabularized and interpreted. As a result of the research, according to Turkish Teaching Undergraduate Program that was put into practice in 2018-2019 academic year, it was detected that there is important changes in issues such as courses, course hours, course contents, course credits.
\end{abstract}

Keywords: faculties of education, undergraduate program, Turkish teaching undergraduate program

\section{Introduction}

One of the fields where the reflections of the changes in science and technology are seen is education. The changes and transformations in education affect the qualifications of the human profile which are aimed to be educated in accordance with the educational policies of the governments. It is desired to train individuals who have skills of 21 st century such as creativity, critical thinking and problem solving, communication and cooperation, information and communication technologies literacy, entrepreneurship and responsibility, etc. (Yalçın, 2018; Black, 2009; Qian \& Clark, 2016; Turiman, Omar, Daud, \& Osman, 2012). As in the past, it will be possible to train individuals who have the qualifications stated today and in the future with the efforts of teachers. Because teachers are the only elements that can operate all components of an education system in harmony with each other. Therefore, teacher training is very important in Turkey as well as in the world.

Teacher training has a long and well-established history in Turkey. The first steps of teacher training in the Ottoman Empire were taken in the era of Fatih Sultan Mehmet (Güven, 2015, p. 208). In the era of Mahmud II firstly, in order to train teachers for Ottoman Junior High Schools, the first teacher school was opened in Istanbul under the name of Dârülmuallimîn (Ottoman Teachers' Training School for Boys) on 16 March 1848 and this is followed by a teachers' training school for girls named Dârülmuallimat in 1870 (Akyüz, 2009, pp. 177-182). When it comes to Republican Period, village teachers' schools were opened in 1927 (Ministry of National Education [MoNE], 2017a), village institutes were established with 3803 numbered law in 1940, thereby Village Teachers' Schools were transformed into Village Institutions (Güven, 2015, p. 208). With the Law published in 1954, institutions trained teachers were merged under the name of Primary Teachers' Training Schools. With the Basic Law of National Education numbered 1739, it was stipulated the provision of higher education to teachers and in 
1974, Primary Teachers' Schools were turned into Training Institutes (Binbaş1oğlu, 2014, p.397; Güven, 2015, p.388) With the Law No 2547 enacted in 1981, village institutions were transformed into Faculties of Education and with the Decree Law numbered 41 enacted in 1982, all institutions that train teachers included to university structure. Since 1989-1990 academic year, the education period of all higher education institutions has been increased to at least undergraduate level (Akyüz, 2009, p. 398; MoNE, 2017a).

When the historical progress of Turkish teacher training in the Republican Period is examined, the first important development is the opening of a two-year Secondary Teachers' School in Konya in the 1926-1927 academic year in order to train Turkish language teachers in secondary schools, first teachers and village teachers' schools. This school was moved to Ankara a year later, and a pedagogical branch was added to the school and the name was changed to Secondary Teacher School and Education Institute. The name of the institute has been Gazi Training Institute since 1949-1950 academic year. In order to meet the needs of Turkish teachers, the number of institutes has been gradually increased and in each of these institutes, the Department of Turkish Teaching has taken its place as a basic department. In 1982, as a result of the transformation of educational institutions into faculties of education and restructuring, it was seen that Turkish Teaching Department was named Turkish Language and Literature Education. Since the absence of a program to train Turkish teachers directly in universities and this situation became a problem in terms of teaching Turkish, in order to train instructor for the Turkish Teaching Program, for the first time, the Department of Education and Teaching of Turkish was established under the Gazi University Institute of Social Sciences to conduct graduate and doctorate programs in 1989-90. Since 1992-1993 academic year, Turkish Language Teaching Department has been established in Gazi University Gazi Education Faculty Turkish Language and Literature Education Department and Dokuz Eylül University Buca Faculty of Education (Özkan \& Şahbaz, 2011; Uçgun, 2006; Güzel, 2003).

In most developed countries, teacher training is handled in four stages as pre-service training, start-up training, in-service training and advanced specialist training. When it comes to teacher training in the field, pre-service training usually comes to mind. Pre-service training of teachers is generally carried out through undergraduate programs of universities (Güneş, 2016, p. 414). In these programs, teacher candidates are given information in three types of content categories as teaching profession knowledge, field knowledge and general culture (Küçükahmet, 2007, p. 207). In order to ensure that training prospective teachers as having general and special field competencies and to achieve the intended quality in education, arrangements are made in these programs in line with the requirements of the age (Göçer, 2018, p. 196). Therefore as changing qualifications and levels of the institution of training teachers in Turkey also has been renovated many times for various reasons. It was seen that the undergraduate programs were updated in 1998 (Grossman \& Sands, 2008) and then in 2006 as a result of the restructuring efforts in order to ensure the unity of teacher training programs of faculties of education. One of the fields where teacher training programs are renewed is Turkish teacher training programs. The undergraduate programs of Turkish Teaching was structured in the 1998-1999 and 2006-2007 academic years (Council of Higher Education [CoHE], 2007), just like the other undergraduate programs. As a final, the Turkish Language Undergraduate Program was updated apply to 1st grades in 2018 (CoHE, 2018a), as of the other teaching undergraduate programs. When the literature is examined, it is seen that there are some studies related to the undergraduate programs of Turkish Teaching (Çoban, 2010; Ateş, 2015; Açık, 2010; Çifci, 2011; Yılmaz, 2014; Özkan \& Şahbaz, 2011). The aim of this study is to examine the Turkish Teaching Program which was restructured in 2018. The study is planned in comparison with the current undergraduate program since 2006-2007 academic year. In this general purpose framework, the answers of following questions were sought:

1) What are the differences of the courses in the renewed program compared to the previous program in terms of theoretical, practical, credit and hour?

2) What are the courses that have been removed from the 2018 Turkish Teaching Undergraduate Program and the newly added courses compared to the previous program?

3) What are the courses whose name is changed and the course contents are updated in 2018 Turkish Teaching Undergraduate Program compared to the previous program?

4) What are the courses whose semesters change in 2018 Turkish Teaching Undergraduate Program compared to the previous program?

5) Which are exactly the courses whose theory and credit changed in 2018 Turkish Teaching Undergraduate Program compared to previous program?

6) What are the he courses that were abolished in 6 Turkish Teaching Undergraduate Program compared to the previous program? 
7) How is the status of the elective courses in the 2018 Turkish Teaching Undergraduate Program compared to the previous program?

\section{Method}

\subsection{Research Design}

This study is a descriptive study in the screening model which aims to make a comparative analysis of Turkish Teaching Undergraduate Program which was restructured in 2018 from the previous program. Screening models are research approaches that aim to describe a past or present situation as it exists. The event, individual or object, which is the subject of the research, are tried to be defined within its own conditions and as it exists. No attempt is made to change or influence events in any way (Karasar, 2006).

\subsection{Study Group}

The study group of the research consists of the 2006-2007 academic year Turkish Teaching Undergraduate Program and the Turkish Teaching Undergraduate Program implemented in the 2018-2019 academic year.

\subsection{Data Collection and Analysis}

The research was structured using qualitative research methods and techniques. Qualitative researches are defined as data collection methods such as observation, interview and document analysis, and a qualitative process for the realistic and holistic presentation of perceptions and events in the natural environment (Yıldırım \& Şimşek, 2006). The data of the study was collected by qualitative research data collection techniques through document analysis. Document analysis includes the analysis of written materials containing information about the case or cases that are aimed to be investigated. In such researches, the researcher can use the data s/he needs as a data collection method alone without the need for observation or interview (Yıldırım \& Şimşek, 2006). In order to obtain the data of the study, Turkish Teaching Undergraduate Program which was put into practice in 2006-2007 academic year and Turkish Teaching Undergraduate Program which was put into practice in 2018-2019 academic year were examined in detail. As a result of the study, the data determined in line with the sub-problems of the study were transferred to the tables prepared in computer environment. In the tables prepared in such a manner that allow to comparison, the theoretical and practical hours and credits of courses in both previous and new program; the courses which are not included in new program and courses that newly added to program; the courses which are included and their contents updated compared to previous program; courses whose semesters were changed in new program compared to previous program and changes related to elective courses took part. Thus, the similarities and differences between the previous program and the new program are clearly identified.

The descriptive analysis technique was used in the analysis of the study data and the data collected about the problem of the research were tabularized and interpreted. The data obtained in the descriptive analysis are summarized and interpreted according to the previously determined themes. The aim of the descriptive analysis is to present the findings to the reader in an edited and interpreted form. The data obtained for this purpose are first described systematically and clearly. Then, descriptions are explained, interpreted and some conclusions are reached (Yıldırım \& Şimşek, 2006).

\section{Results}

\subsection{Findings Related to Differences of the Courses in the Renewed Program Compared to the Previous Program in Terms of Theoretical, Practical, Credit and Hour}

In the 2006 program, there are 59 courses including 30 compulsory and elective courses in the fall semester and 29 compulsory and elective courses in the spring semester. 33 of these courses are Field Education, 14 of them are General Culture and 12 of them are Teaching Knowledge courses. In the 2018 program, there are 68 courses including 35 compulsory and elective courses in the fall semester and 33 compulsory and elective courses in the spring semester. 34 of these courses are Field Education, 12 of them are General Culture and 22 of them are Teaching Knowledge courses. In the statement made by CoHE (2018b) about the reasons for updating programs, innovations and application principles, it is stated that the ratio of Vocational Knowledge courses is $33 \%$, General Culture courses is $18 \%$ and Field Education courses is $49 \%$ in Turkish Teaching Undergraduate Program. In Çoban's (2010, p.964), study, he detected that the rate of Teaching Knowledge courses was $20.3 \%$, the rate of General Culture courses was $23.7 \%$ and the rate of Field Education courses was 55.9\%. According to these data, while the ratio of Teaching Knowledge courses increased in 2018 Program, it was determined that the ratio of General Culture and Field Education courses decreased. In addition, It is determined that there are no courses in the field of General Culture in VII and VIII semesters of the 2018 Program.

The differences in the theoretical, practical, credit and hours of Teaching Knowledge, General Culture and Field 
Education courses compared the previous program are presented in Table 1.

Table 1. The comparison of 2018 Turkish teaching undergraduate program in terms of theoretical, practical, credit and hour

\begin{tabular}{lccccc}
\hline & Program & Theoric & Practice & Credit & Hour \\
\hline \multirow{2}{*}{ Teaching Knowledge } & 2006 & 28 & 14 & 35 & 42 \\
& 2018 & 44 & 12 & 50 & 56 \\
\hline \multirow{2}{*}{ General Culture } & 2006 & 30 & 6 & 33 & 36 \\
& 2018 & 26 & 2 & 27 & 36 \\
\multirow{2}{*}{ Field Education } & 2006 & 70 & 14 & 77 & 88 \\
& 2018 & 73 & 0 & 73 & 73 \\
\multirow{2}{*}{ Total } & 2006 & 128 & 34 & 145 & 162 \\
& 2018 & 143 & 14 & 150 & 157 \\
\hline
\end{tabular}

As in the 2006 Program, the courses in the 2018 Program gathered under three groups as Teaching Knowledge, General Culture and Field Education. According to Table 1, it is seen that the hours (143) of the theoretical courses in the 2018 Program are increased compared to the 2006 Program (128). This difference was mostly experienced in Teaching Knowledge courses. Teaching Knowledge courses which had 28 theoretical hours in the previous program, were increased to 44 in the 2018 Program. Field Education courses which had 70 theoretical hours in the previous program, were increased to 73 in the 2018 Program. However, it was determined that the theoretical hours of General Culture courses were reduced compared to the previous program. When the 2018 Program is examined in terms of practical course hours, it is seen that the practical hours have been considerably reduced compared to the previous program. The practical course hours, which were 34 in the 2006 Program, were reduced to 14 in 2018 Program. It is seen that the application of the Field Education courses in the 2018 Program is 0. In other words, practices of Field Education courses were completely abolished. According to the previous program, Teaching Knowledge courses were reduced by 2 hours and the application of General Culture courses were reduced by 4 hours.

In the 2018 Program (150), it is seen that the credits of the courses have been increased compared to the previous program (145). The main reason for this increase is due to the increase in the credits of Teaching Knowledge courses. Teaching Knowledge courses which were 35 credits in the previous program were increased to 50 in the 2018 Program. On the other hand, it is seen that the credits of General Culture and Field Education courses are reduced. When the total hours of theoretical and practical courses are taken into consideration, the course hours which were 162 in the previous Program were reduced to 157 in the 2018 Program. The most important reason for this situation is to increase the number of theoretical course hours compared to the previous program, but to decrease the practical course hours.

3.2 Findings Related to Courses That Have Been Abolished from the 2018 Turkish Teaching Undergraduate Program and the Newly Added Courses Compared to the Previous Program

The courses that are abolished from the 2018 Turkish Teaching Undergraduate Program and the newly added courses compared to 2006 Program are presented in Table 2. 
Table 2. The Courses that have been removed from the 2018 Turkish teaching undergraduate program and the newly added courses compared to the previous program

\begin{tabular}{|c|c|c|}
\hline Semesters & Abolished Courses & Newly Added Courses \\
\hline \multirow{3}{*}{ I } & Writing Techniques (FE) & Educational Philosophy (TK) \\
\hline & Written Expression I (FE) & Turkish Language 1 (GC) \\
\hline & Verbal lecture I (FE) & Information Technologies (GC) \\
\hline \multirow{3}{*}{ II } & \multirow{3}{*}{$\begin{array}{l}\text { Written Expression II (FE) } \\
\text { Verbal Lecture II (FE) }\end{array}$} & Education Sociology (TK) \\
\hline & & Turkish Language 2 (GC) \\
\hline & & Basic Concepts of Language Education (FE) \\
\hline III & Computer I (GC) & Turkish Learning and Teaching Approaches (FE) \\
\hline \multirow{2}{*}{ IV } & Computer II (GC) & \multirow{2}{*}{ Turkish Teaching Programs (FE) } \\
\hline & Effective Communication (GC) & \\
\hline $\mathrm{V}$ & Special Teaching Methods I (TK) & Moral and Ethics in Education (TK) \\
\hline \multirow{2}{*}{ VI } & History of Civilization (GC) & \multirow{2}{*}{ Textolinguistics (FE) } \\
\hline & Special Education Methods II (FE) & \\
\hline \multirow{2}{*}{ VII } & Turkish Textbook Reviews (FE) & Grammar Teaching (FE) \\
\hline & School Experience (TK) & Teaching Practice 1 (TK) \\
\hline \multirow{2}{*}{ VIII } & Language and Culture (GC) & \multirow{2}{*}{ Teaching Practice 2 (TK) } \\
\hline & Teaching Practice (TK) & \\
\hline
\end{tabular}

Note. TK: Teaching Knowledge, GC: General Culture, FE: Field Education.

According to Table 2, Writing Techniques, Written Expression I-II, Verbal Lecture I-II, Computer I-II, Effective Communication, Special Teaching Techniques I-II, History of Civilization, Turkish Textbook Reviews, School Experience, Teaching Practice and Language and Culture Courses were abolished in 2018 Turkish Teaching Undergraduate Program. However, it is possible to say that the contents of Written Expression I and II courses intersect at some points with the content of Turkish Language 1 course. It can be stated that Computer I and II courses are given under the name of Information Technologies in one semester. Effective Communication course which was compulsory course in 2006 program under Human Relations and Communication under General Culture elective course in 2018 program, Turkish Textbook Reviews compulsory course in 2006 Program under Field Education elective course in 2018, Language and Culture compulsory course in 2006 Program under General Culture elective course as Culture and Language course in 2018 program were given with partially similar content. The School Experience course was abolished and combined with the content of the Teaching Practice course and it took place in the 2018 Program in two terms as Teaching Practice 1 and Teaching Practice 2.

Educational Philosophy, Turkish Language 1-2, Information Technologies, Education Sociology, Basic Concepts of Language Education, Turkish Learning and Teaching Approaches, Turkish Teaching Programs, Moral and Ethics in Education, Textolinguistics and Grammar Teaching courses are seen as compulsory courses in 2018 Program.

When Table 2 is examined, when looked at courses which were compulsory courses in 2006 program but abolished in 2018 program, it is seen that 7 courses are in Field Education, 5 courses are in General Culture and 3 courses are in Teaching Knowledge field. When the compulsory new courses in the 2018 Program are examined, it is determined that 5 courses are in Field Education, 3 courses in General Culture and 5 courses in Teaching Knowledge.

3.3 Findings Related to the Courses Whose Name Is Changed and the Course Contents Are Updated in 2018 Turkish Teaching Undergraduate Program Compared to the Previous Program

The courses whose name is changed and updated in the 2018 Turkish Teaching Undergraduate Program compared to 2006 Turkish Teaching Undergraduate Program are presented in Table 3. 
Table 3. The courses whose name is changed and the course contents are updated in 2018 Turkish teaching undergraduate program compared to the previous program

\begin{tabular}{ll}
\hline 2006 Undergraduate Program & 2018 Undergraduate Program \\
\hline Turkish Grammar I: Phonetics & Turkish Grammar 1 \\
Turkish Grammar II: Morphology & Turkish Grammar 2 \\
Turkish Grammar III: Vocabulary & Turkish Grammar 3 \\
Turkish Grammar IV: Sentence Knowledge & Turkish Grammar 4 \\
Introduction to Teaching Profession & Introduction to Education \\
Instructional Technologies and Material Design & Instructional Technologies \\
Scientific Research Methods & Research Methods in Education \\
General Linguistics & Linguistics \\
Teaching Turkish to Foreigners & Teaching Turkish as a Foreign Language \\
Special Education & Special Education and Inclusion \\
Guidance & Guidance in Schools \\
Comprehension Techniques I: Reading Education & Reading Education \\
Comprehension Techniques II: Listening Education & Listening Education \\
Comprehension Techniques III: Speaking Education & Speaking Education \\
Narration Techniques II: Writing Education & Writing Education \\
Assessment and Evaluation & Assessment and Evaluation in Education \\
\hline
\end{tabular}

According to Table 3, it is seen that some compulsory courses in the 2006 Program are included in the 2018 Program with updated contents. Among these courses, it is possible to say that the Instructional Technologies and Material Design course, which is 2 hours of theoretical and 2 hours of practice in the field of Teaching Knowledge as a compulsory course in 2006 Program, is divided into two in the 2018 Program. This course is compulsory with 2 hours of theory in the field of Teaching Knowledge in the name of Instructional Technologies in the 2018 Program and 2 hours of theory in the field of elective courses in the field of Material Education in Turkish Teaching. The Scientific Research Methods course, which is also compulsory in the 2006 Program, took place in the 2018 Program under the name Research Methods in Education. However, some of the content of this course is also found in the content of Turkish Language 2 course in 2018 Program.

\subsection{Findings Related to the Courses Whose Semesters Change in Semesters of 2018 Turkish Teaching Undergraduate Program Compared to the Previous Program}

The courses whose name are same and have similar content but semesters changed in the 2018 Turkish Teaching Undergraduate Program compared to 2006 Turkish Teaching Undergraduate Program are presented in Table 4.

Table 4. Courses whose semesters change in 2018 turkish teaching undergraduate program compared to the previous program

\begin{tabular}{llll}
\hline Semesters & 2006 Undergraduate Program & Semesters & 2018 Undergraduate Program \\
\hline I & - & I & - \\
II & - & II & - \\
III & Scientific Research Methods & IV & Research Methods in Education \\
IV & Instructional Technologies and Material Design & III & Instructional Technologies \\
IV & General Linguistics & V & Linguistics \\
V & Children's Literature & III & Children's Literature \\
V & World Literature & VIII & World Literature \\
VI & History of Turkish Education & IV & History of Turkish Education \\
VI & Teaching Turkish to Foreigners & VIII & Teaching Turkish as a Foreign Language \\
VII & Guidance & VIII & Guidance in Schools \\
VIII & Turkish Education System and School Management & VI & Turkish Education System and School Management \\
\hline
\end{tabular}

According to Table 4, it is seen that the semesters of some compulsory courses included in the 2016 Program are changed in the 2018 Program. For example; Children Literature courses in V semester of 2006 program found a place for itself in III semester of 2018 Program, World Literature in V. semester of 2006 Program had a place for itself in VIII semester of 2018 program, and Turkish Education System and School Management course in VIII 
semester of 2006 found a place for itself in VI semester of 2018 program. In I and II semesters, the semester of any course has not changed.

\subsection{Findings Related to Courses Which Are Exactly Included in 2018 Turkish Teaching Undergraduate Program and Whose Theory and Credit Changed Compared to Previous Program}

The compulsory courses whose theory and credit changed in 2018 Turkish Teaching Undergraduate Program compared 2006 program.

Table 5. Courses which are exactly included in 2018 Turkish teaching undergraduate program and whose theory and credit changed compared to previous program

\begin{tabular}{|c|c|c|c|c|c|}
\hline 2006 Undergraduate Program & & & 2018 Undergraduate Program & & \\
\hline Course name & $\mathrm{T}$ & $\mathrm{C}$ & Course name & $\mathrm{T}$ & \\
\hline Introduction to Teaching Profession & 3 & 3 & Introduction to Education & 2 & 2 \\
\hline Foreign Language I & 3 & 3 & Foreign Language 1 & 2 & 2 \\
\hline Education Psychology & 3 & 3 & Education Psychology & 2 & 2 \\
\hline Foreign Language II & 3 & 3 & Foreign Language 2 & 2 & 2 \\
\hline Teaching Principles and Methods & 3 & 3 & Teaching Principles and Methods & 2 & 2 \\
\hline Computer I & 2 & 3 & Information Technologies & 3 & $3+3>>>3$ \\
\hline Computer III & 2 & 3 & 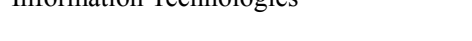 & & \\
\hline Instructional Technologies and Material Design & 2 & 3 & Instructional Technologies & 2 & 2 \\
\hline Comprehension Techniques I: Reading Education & 2 & 3 & Reading Education & 3 & 3 \\
\hline Comprehension Techniques II: Listening Education & 2 & 3 & Listening Education & 3 & 3 \\
\hline General Linguistics & 3 & 3 & Linguistics & 2 & 2 \\
\hline Comprehension Techniques I: Speaking Education & 2 & 3 & Speaking Education & 3 & 3 \\
\hline Narration Techniques II: Writing Education & 2 & 3 & Writing Education & 3 & 3 \\
\hline Assessment and Evaluation & 3 & 3 & Assessment and Evaluation in Education & 2 & 2 \\
\hline Theater and Drama Applications & 2 & 3 & Theater and Drama Applications & 2 & 2 \\
\hline Guidance & 3 & 3 & Guidance in Schools & 2 & 2 \\
\hline Teaching Turkish to Foreigners & 2 & 2 & Teaching Turkish as a Foreign Language & 3 & \\
\hline
\end{tabular}

Note. T: Theoric, C: Credit.

According to Table 5, although some compulsory courses in the 2006 Program are also in the 2018 Program, it has been determined that the theoretical hours and credits of the courses changed. 2006 Program which includes 3 hours of theory and 3 hours of credits in Introduction to Educational Science, Foreign Language I-II, Educational Psychology, Teaching Principles and Methods, General Linguistics, Assessment and Evaluation, Guidance courses are reduced to 2 hours of theory and 2 hours of credits in new program. In the 2006 Program, Computer I course and Computer II course with two hours of theory and three hours of credit were combined with the name of Information Technology course in the new program and the theory and credit were included as 3 . In the 2006 program, Instructional Technologies and Material Design course, which is 2 hours of theory and 3 hours of credit, is given as the compulsory Instructional Technologies ( 2 hours of theory 2 hours of credits) and Material Design in Turkish Teaching as elective of Field Education ( 2 hours of theory 2 credits) is given in the new program. The theory of Theater and Drama Practices course was determined as 2 hours in the new program, but its credits were reduced from 3 hours to 2 hours. The credits of Reading Education, Listening Education, Speaking Education and Writing Education remained the same in the new program ( 3 credits), but the theoretical hours of 2 were increased to 3 hours. In the new program, both theoretical course hours ( 3 hours) and credits ( 3 credits) of Turkish Teaching to Foreigners ( 2 hours theory and 2 credits) were increased.

3.6 Findings Related to Courses That Have Been Abolished from the 2018 Turkish Teaching Undergraduate Program Compared to the Previous Program

Courses that have been abolished from the 2018 Turkish Teaching Undergraduate Program compared to the 2006 program are presented in Table 6. 
Table 6. The courses that were abolished in 2018 Turkish teaching undergraduate program compared to the previous program

\begin{tabular}{llll}
\hline 2006 Undergraduate Program & & 2018 Undergraduate Program \\
\hline Course name & P & Course name & P \\
Computer I & 2 & Information Technologies & 0 \\
Computer III & 2 & & 0 \\
Instructional Technologies and Material Design & 2 & Instructional Technologies & 0 \\
Comprehension Techniques I: Reading Education & 2 & Reading Education & 0 \\
Comprehension Techniques II: Listening Education & 2 & Listening Education & 0 \\
Comprehension Techniques I: Speaking Education & 2 & Speaking Education & 0 \\
Narration Techniques II: Writing Education & 2 & Writing Education & 0 \\
Theater and Drama Applications & 2 & Theater and Drama Applications & 0 \\
\hline
\end{tabular}

Note. P: Practice.

According to Table 6, Computer I-II, Instructional Technologies and Material Design, Reading Education, Listening Education, Speaking Education, Writing Education and Theater and Drama Practices courses, which have the 2 hours of practices in 2006 Program, are abolished. The most of the courses that have been abolished in the new program are Field Education courses.

\subsection{Findings Related to Courses Whose Semesters Change in 2018 Turkish Teaching Undergraduate Program Compared to the Previous Program}

The elective courses in the 2018 Program are presented in Table 7.

Table 7. Elective courses in 2018 Turkish language teaching undergraduate program

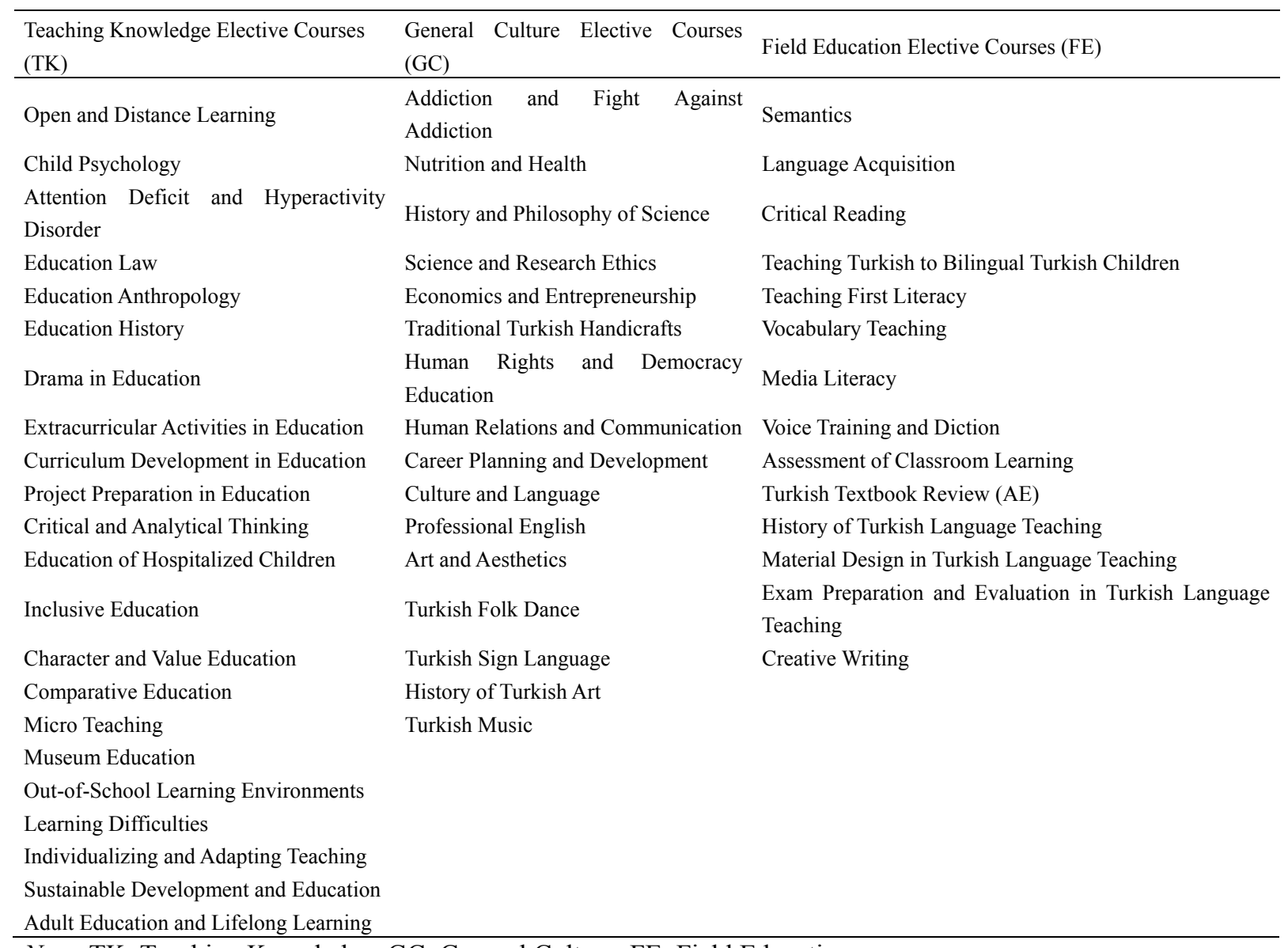

Note. TK: Teaching Knowledge, GC: General Culture, FE: Field Education. 
According to Table 7, there are 22 Teaching Knowledge, 16 General Culture and 14 Field Education elective courses in the 2018 Program. Effective Communication compulsory course in 2006 program were given as elective Human Relations and Communication Course in new program, Language and Culture compulsory course in 2006 program were given as elective Culture and Language in new program, Turkish Textbook Reviews compulsory course in 2006 program were given as elective Turkish Textbook Review in new program. In the new program, Instructional Technologies and Material Design course is given as Instructional Technologies as compulsory and elective as Material Education in Turkish Teaching as elective. However, it should be said that the contents of the courses do not exactly match. For example in the 2006 Program, "language" was emphasized in the Language and Culture course. In the Culture and Language course, which is included in the 2018 Program as a Field Education elective, the "culture" dimension gained weight. The status of the elective courses in 2006 and 2018 Program is presented in Table 8.

Table 8. Comparison of semester, theoretical and practical hours and credits of elective courses in 2006 and 2018 program

\begin{tabular}{|c|c|c|c|c|c|c|c|c|c|}
\hline \multicolumn{5}{|c|}{2006 Undergraduate Program } & \multicolumn{5}{|c|}{2018 Undergraduate Program } \\
\hline Semester & Course name & $\mathrm{T}$ & $\mathrm{P}$ & $\mathrm{C}$ & Semester & Course name & $\mathrm{T}$ & $\mathrm{P}$ & $\mathrm{C}$ \\
\hline $\mathrm{I}$ & - & - & - & - & $\mathrm{I}$ & - & - & - & - \\
\hline II & - & - & - & - & II & - & - & - & - \\
\hline \multirow{2}{*}{ III } & \multirow{2}{*}{ Elective I (FE) } & \multirow{2}{*}{3} & \multirow{2}{*}{0} & \multirow{2}{*}{3} & \multirow{2}{*}{ III } & Elective $1(\mathrm{TK})$ & 2 & 0 & 2 \\
\hline & & & & & & Elective $1(\mathrm{GC})$ & 2 & 0 & 2 \\
\hline \multirow{3}{*}{ IV } & \multirow{3}{*}{-} & \multirow{3}{*}{-} & \multirow{3}{*}{-} & \multirow{3}{*}{ - } & \multirow{3}{*}{ IV } & Elective 2 (TK) & 2 & 0 & 2 \\
\hline & & & & & & Elective 2 (GC) & 2 & 0 & 2 \\
\hline & & & & & & Elective $1(\mathrm{FE})$ & 2 & 0 & 2 \\
\hline \multirow{3}{*}{$\mathrm{V}$} & \multirow{3}{*}{-} & \multirow{3}{*}{-} & \multirow{3}{*}{-} & \multirow{3}{*}{\multicolumn{2}{|c|}{$\mathrm{V}$}} & Elective 3 (TK) & 2 & 0 & 2 \\
\hline & & & & & & Elective 3 (GC) & 2 & 0 & 2 \\
\hline & & & & & & Elective $2(\mathrm{FE})$ & 2 & 0 & 2 \\
\hline \multirow{3}{*}{ VI } & \multirow{3}{*}{-} & \multirow{3}{*}{-} & \multirow{3}{*}{\multicolumn{2}{|c|}{ - }} & \multirow{3}{*}{ VI } & Elective 4 (TK) & 2 & 0 & 2 \\
\hline & & & & & & Elective 4 (GC) & 2 & 0 & 2 \\
\hline & & & & & & Elective 3 (FE) & 2 & 0 & 2 \\
\hline \multirow{3}{*}{ VII } & \multirow{3}{*}{ Elective I (GC) } & \multirow{3}{*}{2} & \multirow{3}{*}{0} & \multirow{3}{*}{2} & \multirow{3}{*}{ VII } & Elective 5 (TK) & 2 & 0 & 2 \\
\hline & & & & & & Elective 4 (FE) & 2 & 0 & 2 \\
\hline & & & & & & Elective $5(\mathrm{FE})$ & 2 & 0 & 2 \\
\hline \multirow{3}{*}{ VIII } & Elective II (FE) & 3 & 0 & 3 & \multirow{3}{*}{ VIII } & Elective $6(\mathrm{TK})$ & 2 & 0 & 2 \\
\hline & Elective III (FE) & 2 & 0 & 2 & & Elective $6(\mathrm{FE})$ & 2 & 0 & 2 \\
\hline & Elective II (GC) & 2 & 0 & 2 & & & & & \\
\hline
\end{tabular}

Note. TK: Teaching Knowledge, GC: General Culture, FE: Field Education T: Theoric, P: Practice C: Credit.

According to Table 8, it is seen that elective courses are given in VII and VIII semesters. 3 of these courses are elective of Field Education and 2 of them elective of General Culture. Theoretical hours and credits of elective courses in the field of General Culture are 2. 2 of the elective courses in Field Education are 3 hours of theory and 3 credits, while 1 of them is 2 hours of theory and 2 credits. When the 2018 Program is examined in terms of elective courses, it is seen that the number of elective courses and the semesters are increased. In addition, the theory of all elective courses in the field of General Culture, Teaching Knowledge and Field Education has been determined as 2 hours and 2 credits. Another important point in both programs related to elective courses is the absence of elective courses in I and II semesters and the lack of practical hours of elective courses.

\section{Discussion and Conclusion}

In this study, it was aimed to evaluate the Turkish Teaching Program which was restructured in 2018 by comparing it with the current undergraduate program since 2006-2007 academic year. As a result of the findings obtained from the first sub-problem of the study, it was found that the hours of theoretical courses in the 2018 Program were increased compared to the 2006-2007 Program. The most significant increase in theoretical courses was observed in Teaching Knowledge courses. However, it was determined that the theoretical hours of General Culture courses were reduced compared to the previous program. When the 2018 Program is examined in terms of practical course hours, it is seen that the practical hours have been considerably reduced compared to the previous program. 
Especially, practice of Field Education courses were completely abolished in 2018 Program. In the study of Çoban (2010) where he compared the Turkish Teaching Undergraduate Program applied since the 1998-1999 academic year and the Turkish Teaching Undergraduate Program applied since the 2006-2007 academic year, it was concluded that the practical hours of the courses were not sufficient and it has been proposed to increase practical hours. In the studies of Taş, Kunduroğlu-Akar, and Kıroğlu (2017) evaluating the Undergraduate Program of Classroom Teaching in line with the opinions of academicians and prospective teachers, it was stated that the theoretical hours of the courses could be reduced and more practical hours could be added. Although the studies related to the previous undergraduate programs have been proposed to decrease the theoretical hours and increase the practical hours, it is seen that this situation continues in the new program. In the 2018 Program, the credits of the courses were increased compared to the previous program. However, the main reason for this increase is due to the increase in the credits of Teaching Knowledge courses. On the other hand, it is seen that the credits of General Culture and Field Education courses are reduced. When the total hours of theoretical and practical courses are taken into consideration, the course hours which were 162 in the previous Program were reduced to 157 in the 2018 Program.

As a result of findings obtained second sub problem of the study, Writing Techniques, Written Expression I-II, Verbal Lecture I-II, Computer I-II, Effective Communication, Special Teaching Techniques I-II, History of Civilization, Turkish Textbook Reviews and Language and Culture courses in 2006 Program were abolished in 2018 Turkish Teaching Undergraduate Program. According to the previous program, it can be said that the most striking course among the courses not included in the 2018 Program is the Special Teaching Methods given in the 5th and 6th semesters. Perhaps the most important deficiency of the program is the absence of Special Teaching Methods in the new program. Because, in this course, students have the opportunity to practical field education courses related to four basic language skills with different approaches, methods and techniques. Therefore, the abolition of the course can be considered as a negative aspect of the program. In the study of Akyüz, Özcan, and Altiparmak (2015) that they aimed to determine the views of prospective Turkish teachers about Turkish special teaching methods course, it was determined that the prospective teachers' knowledge and skills they learned from Special Teaching Methods courses would contribute to their professional lives, and the duration of the course separated for practical should be increased. Educational Philosophy, Turkish Language 1-2, Information Technologies, Education Sociology, Basic Concepts of Language Education, Turkish Learning and Teaching Approaches, Turkish Teaching Programs, Moral and Ethics in Education, Textolinguistics and Grammar Teaching courses are compulsory courses in 2018 Program. The fact that the basic concepts of Language Education, Turkish Learning and Teaching Approaches, Turkish Teaching Programs, Grammar Teaching courses are included in the 2018 Program is the positive qualifications of Program. In the new program, there has been a partial decrease in the fields of Field Education and General Culture in terms of compulsory courses, while there has been a partial increase in General Culture courses. It can also be stated that the contents of Written Expression I and II courses intersect at some points with the content of Turkish Language 1 course and Computer I and II courses are given under the name of Information Technologies in a single semester. Effective Communication compulsory course in 2006 program under Human Relations and Communication under General Culture elective course in 2018 program, Turkish Textbook Reviews course under Field Education elective course as Turkish Textbook Review in 2018, Language and Culture compulsory course in 2006 Program under General Culture elective course as Culture and Language course in 2018 program were given with partially similar content.

As a result of the findings obtained from the third sub-problem of the study, it was found that names of some compulsory courses in the 2006 Program have been changed in the 2018 Program and have same contents. For instance, Introduction to Education Science in the 2006 program took part as Introduction to Education in the 2018 Program, General Linguistics course in the 2006 program found a place with the name of Linguistics in the 2018 Program, Teaching Turkish to Foreigners in the 2006 program took part with the name of Teaching Turkish as a Foreign Language, Guidance in the 2006 program, Guidance course in 2006 program took place under the name of Guidance in schools in the 2018 Program. Among the courses whose name changed in 2018 Program and have similar content compared to previous program, it is possible to say that the Instructional Technologies and Material Design course, which is 2 hours of theoretical and 2 hours of practice in the field of Teaching Knowledge as a compulsory course, is divided into two in the new program. This course is compulsory with 2 hours of theory in the field of Teaching Knowledge in the name of Instructional Technologies in the 2018 Program and 2 hours of theory in the field of elective courses in the field of Material Education in Turkish Teaching. The Scientific Research Methods course, which is also compulsory in the 2006 Program, took place in the 2018 Program under the name Research Methods in Education. However, some of the content of this course is also found in the content of Turkish Language 2 course in 2018 Program. 
As a result of the findings obtained from the fourth sub-problem of the study, it was found that semesters of some compulsory courses in the 2006 Program have been changed in the 2018 Program. For example; Children Literature courses in V. semester of 2006 program was included in III semester of 2018 Program, World Literature in V. semester of 2006 Program was included in VIII semester of 2018 program, and Turkish Education System and School Management course in VIII semester of 2006 took part in VI semester of 2018 program. In addition, there was no course whose semester is changed in I and II semesters. Another point that should be emphasized here is that the Theatre and Drama Practices course, which is compulsory in the VII semester of the 2006 Program, will be given in the 2018 Program in the same semester. In several studies on this subject (Özkan \& Şahbaz, 2011; Doğan \& Özberk, 2013), prospective teachers stated that this course should be given in the previous semesters, especially because of the KPSS (public personnel selection examination) exam.

As a result of the findings obtained from the fifth sub-problem of the study, it was found that theoretical hours and credits of some compulsory courses in the 2006 Program have been changed in the 2018 Program. For instance, 2006 Program which includes 3 hours of theory and 3 hours of credits in Introduction to Educational Science, Foreign Language I-II, Educational Psychology, Teaching Principles and Methods, General Linguistics, Assessment and Evaluation, Guidance courses are reduced to 2 hours of theory and 2 hours of credits in new program. In the 2006 Program, it is determined that Computer I course and Computer II course with two hours of theory and three hours of credit were combined with the name of Information Technology course in the new program and the theory and credit were included as 3. In the 2006 program, Instructional Technologies and Material Design course, which is 2 hours of theory and 3 hours of credit, is given as the compulsory Instructional Technologies ( 2 hours of theory 2 hours of credits) and Material Design in Turkish Teaching as elective of Field Education ( 2 hours of theory 2 credits) is given in the new program. The theory of Theater and Drama Practices course was determined as 2 hours in the new program, but its credits were reduced from 3 hours to 2 hours. The credits of Reading Education, Listening Education, Speaking Education and Writing Education remained the same in the new program, but the theoretical hours of 2 were increased to 3 hours. In the new program, both theoretical course hours and credits of Turkish Teaching to Foreigners were increased.

As a result of the findings obtained from the sixth sub-problem of the study, it was found that practical hours of some compulsory courses in the 2006 Program have been removed in the 2018 Program. In the 2006 program, the hours of practice of Reading Education, Listening Education, Speaking Education, Writing Education and Theater and Drama Applications, which have 2 hours of practice, have been abolished. It has been determined that most of the courses that have been abolished in the new program are Field Education courses. In the study of Koç (2018), which he examined the attitudes of prospective Turkish teacher candidates towards speech education course, he stated that this course, which consists of 2 hours of theory and 2 hours of practice, should not only be taught as theory, but also the practice should be included. In the study of Sevim and Şeref (2015) which tried to determine the opinions and suggestions of prospective Turkish teachers about reading education course, they found that practice activities were not included enough in reading education courses. Therefore, it is recommended to increase the practical hours. Research shows that more time is needed to practice, especially in courses related to comprehension and expression skills. However, contrary to this situation, it is seen that even the current practical hours have been abolished in the 2018 Program. In the Teacher Strategy Document 2017-2023 (MoNE, 2017b), actions were taken to improve training in teacher training programs". The third of these actions is "Restructuring of teacher training programs weighed in practice". However, when the restructured program is examined, it is seen that the practice has been abolished in many field courses. This situation is thought to be in contradiction. In the statement made by CoHE (2018b) about the reasons for updating the programs, the innovations it brought and the principles of practice the following statements regarding the practice course hours were included: "The absence of practical hours in the weekly course schedules does not mean that there will be no practices in these courses, and although the practice course hours/credits are not given, students should be encouraged to make observations and practices related to the course in various environments (school, classroom, environment, laboratory etc.)."

As a result of the findings obtained from the seventh sub-problem of the study, it was found that there are 22 Teaching Knowledge, 16 General Culture and 14 Field Education elective courses in 2018 Program. Effective Communication compulsory course in 2006 program were given as elective Human Relations and Communication Course in new program, Language and Culture compulsory course in 2006 program were given as elective Culture and Language in new program, Turkish Textbook Reviews compulsory course in 2006 program were given as elective Turkish Textbook Review in new program. In the new program, Instructional Technologies and Material Design course is given as Instructional Technologies as compulsory and elective as Material Education in Turkish Teaching as elective. However, it should be said that the contents of the courses do not exactly match. In the 2006 Program, elective courses are mainly given in VII and VIII semesters. When the 2018 Program is examined in 
terms of elective courses, it is seen that the number of elective courses and the semesters are increased. As of the third semester, elective courses are generally equally distributed. Another noteworthy change regarding the elective courses is that there are no elective courses in the field of Teaching Knowledge in the 2006 Program, but elective courses in the field of Teaching Knowledge are also included in the 2018 Program. The theory of all elective courses in the field of General Culture, Teaching Knowledge and Field Education in new program has been determined as 2 hours and 2 credits. An important issue related to elective courses is the absence of elective courses in the I and II semesters and the lack of practical hours of elective courses in the 2018 Program as in the previous program. According to the results of the study it is possible to list the suggestions as follows:

- Especially, practices of field education courses related to basic language skills should be re-included in the program. If these courses will not have practices, Special Teaching Methods I-II courses should be re-included in the program.

- Some courses such as Vocabulary Teaching, Human Relations and Communication, History of Turkish Teaching which are in the elective courses category, can be determined as compulsory courses.

- Some of the elective courses in the 2018 Program may also include practical hours. Because, although it is stated in the course content that the practice will be made in the course, it is seen that the course does not have practical hour. For example; in the content of Micro Teaching course as an elective course, although there is a statement such as "sample course practices in the classroom, video recording of courses, evaluation of the course by making use of records, development of prepared activities and courses", it is seen that there is no practical hours of the course.

- It may be suggested that the semester in which Theater and Drama Practices course is given should be taken earlier.

\section{References}

Açık, F. (2010). Türkçe öğretmeni yetiştirme programında mevcut alan derslerinin kültürel boyutu. TÜBAR, XXVII, 15-26. Retrieved from http://turkoloji.cu.edu.tr/YENI\%20TURK\%20DILI/fatma_acik_turkce_ ogretmeni_yetistirme.pdf

Akyüz, E., Özcan, Ş. \& Altıparmak, H. M. (2015). Türkçe öğretmeni adaylarının Türkçe özel öğretim yöntemleri dersine ilişkin görüşleri. Dil Eğitimi ve Araştırmaları Dergisi, 1(1), 65-76. Retrieved from http://dergipark.org.tr/jlere/issue/18969/200365

Akyüz, Y. (2009). Türk eğitim tarihi (14. bask1). Ankara: Pegem Akademi Yay.

Ateş, M. (2015). Türkçe öğretmenliği lisans programlarının öğretmen yeterlikleri açısından incelenmesi. The Journal of Academic Social Science, 11(41), 293-301. https://doi.org/10.9761/JASSS3175

Binbaşığlu, C. (2014). Başlangıçtan günümüze Türk eğitim tarihi (2. bask1). Ankara: Anı Yay.

Black, R. W. (2009). English-language learners, fan communities, and 21st-century skills. Journal of Adolescent \& Adult Literacy, 52(8), 688-697. https://doi.org/10.1598/JAAL.52.8.4

Council of Higher Education. (2007). Ĕ̈itim fakültesi ögretmen yetiştirme lisans programları. Ankara.

Council of Higher Education. (2018a). Yeni ögretmen yetiştirme lisans programları. Retrieved from https://www.yok.gov.tr/kurumsal/idari-birimler/egitim-ogretim-dairesi/yeni-ogretmen-yetistirme-lisans-prog ramlari

Council of Higher Education. (2018b). Programların güncelleme gerekçeleri, getirdiği yenilikler ve uygulama esaslarl. Retrieved from https://www.yok.gov.tr/Documents/Kurumsal/egitim_ogretim_dairesi/YeniOgretmen-Yetistirme-Lisans-Programlari/AA_Sunus_\%20Onsoz_Uygulama_Yonergesi.pdf

Çifci, M. (2011). Türkçe öğretmeni yetiştirme programı sorunu. Turkish Studies, 6(1), 403-410. https://doi.org/10.7827/turkishstudies.2021

Çoban, A. (2010). Türkçe öğretmenliği lisans programlarının değerlendirilmesi. Turkish Studies, 5(3), 958-976. https://doi.org/10.7827/turkishstudies.1634

Doğan, B., \& Özberk, E. H. (2013). Türkçe öğretmeni adaylarının tiyatro ve drama uygulamaları dersine ilişkin tutumlarının belirlenmesi. Eğitim ve Ögretim Araştırmaları Dergisi, 2(1), 253-263. Retrieved from http://www.jret.org/FileUpload/ks281142/File/27.bahar_dogan.pdf

Göçer, A. (2018). Türkçe öğretmeni özel alan yeterliklerinin ölçme değerlendirme bileşenleri ve performans göstergeleri bağlamında incelenmesi. Bitlis Eren Üniversitesi Sosyal Bilimler Enstitüsü Dergisi, 7(1), 
194-210. Retrieved from https://dergipark.org.tr/download/article-file/497087

Grossman, G.. M., \& Sands, M. K. (2008). Restructuring reforms in Turkish teacher education: Modernisation and development in a dynamic environment. International Journal of Educational Development, 28(1), 70-80. https://doi.org/10.1016/j.ijedudev.2007.07.005

Güneş, F. (2016). Öğretmen yetiştirme yaklaşım ve modelleri. Ahi Evran Üniversitesi Kırşehir Eğitim Fakültesi Dergisi, 17(3), 413-435. Retrieved from http://kefad2.ahievran.edu.tr/archieve/pdfler/Cilt17Sayi3/JKEF_17 _3_2016_413-435.pdf

Güven, İ. (2015). Türk eğitim tarihi (6. bask1). Ankara: Pegem Akademi Yay.

Güzel, A. (2003). Türkçenin eğitimi-öğretimi bölümlerinde kurulması gerekli görülen anabilim dalları hakkında yeni projelerimiz. Selçuk Üniversitesi Türkiyat Araştırmaları Dergisi, 13, 63-86. Retrieved from http://sutad.selcuk.edu.tr/sutad/article/view/207/199

Karasar, N. (2006). Bilimsel araştırma yöntemi. Ankara: Nobel Yayıncılık.

Koç, G. C. (2018). Türkçe öğretmeni adaylarının konuşma eğitimi dersine yönelik tutumları. International Journal of Innovative Approaches in Education, 2(2), 34-45. https://doi.org/10.29329/ijiape.2018.148.1

Küçükahmet, L. (2007). 2006-2007 öğretim yılında uygulanmaya başlanan öğretmen yetiştirme lisans programlarının değerlendirilmesi. Türk Eğitim Bilimleri Dergisi, 5(2), 203-218. Retrieved from https://dergipark.org.tr/download/article-file/256344

Ministry of National Education. (2017a). Öğretmenlik mesleği genel yeterlikleri. Ankara. Retrieved from https://oygm.meb.gov.tr/meb_iys_dosyalar/2017_12/11115355_YYRETMENLYK_MESLEYY_GENEL_Y ETERLYKLERY.pdf

Ministry of National Education. (2017b). Öğretmen Strateji Belgesi (2017-2023). Ankara. Retrieved from http://oygm.meb.gov.tr/meb_iys_dosyalar/2017_06/09140719_Strateji_Belgesi_Resmi_Gazete_sonrasY_ila n.pdf

Özkan, B., \& Şahbaz, N. K. (2011). Türkçe öğretmeni adaylarının alan derslerinin işlevselliğine yönelik görüşleri. Sakarya University Journal of Education, 1(1), 32-43. Retrieved from https://dergipark.org.tr/download/article-file/192249

Qian, M., \& Clark, K.R. (2016). Game-based learning and 21st century skills: A review of recent research. Computers in Human Behavior, 63, 50-58. https://doi.org/10.1016/j.chb.2016.05.023

Sevim, O., \& Şeref, İ. (2015). Türkçe öğretmen adaylarının okuma eğitimi dersiyle ilgili görüş ve önerileri. Ekev Akademi Dergisi, $\quad 19(61), \quad 343-356 . \quad$ Retrieved from http://www.ekevakademi.org/Makaleler/1525692042_15\%20Oguzhan\%20SEVIM-Izzet\%20SEREF.pdf

Taş, İ. D., Kunduroğlu-Akar, T., \& Kıroğlu, E. (2017). Sınıf öğretmenliği lisans programının öğretim üyeleri ve öğretmen adaylarının görüşleri doğrultusunda değerlendirilmesi. Yükseköğretim ve Bilim Dergisi, 7(3), 578-592. Retrieved from http://oaji.net/articles/2017/593-1527841485.pdf

Turiman, P., Omar, J., Daud, A. M., \& Osman, K. (2012). Fostering the $21^{\text {st }}$ century skills through scientific literacy and science process skills. Procedia-Social and Behavioral Sciences, 59, 110-116. https://doi.org/10.1016/j.sbspro.2012.09.253

Uçgun, D. (2006). Cumhuriyet döneminde Türkçe öğretmenlerinin yetiştirilmesi (Yayınlanmamış Doktora Tezi). Gazi Üniversitesi Eğitim Bilimleri Enstitüsü, Ankara.

Yalçın, S. (2018). 21. yüzyıl becerileri ve bu becerilerin ölçülmesinde kullanılan araçlar ve yaklaşımlar. Ankara Üniversitesi Eğitim Bilimleri Fakültesi Dergisi, 51(1), 183-201. https://doi.org/10.30964/auebfd.405860

Yıldırım, A., \& Şimşek, H. (2006). Sosyal bilimlerde nitel araştırma yöntemleri. Ankara: Seçkin Yayıncılık.

Yılmaz, O. (2014). Türkiye ve Kazakistan'da okutulan Türkçe öğretmenliği lisans programlarının karşılaştırılması üzerine bir çalışma. Erzincan Üniversitesi Eğitim Fakültesi Dergisi, 16(2), 184-203. https://doi.org/10.17556/jef.96207 


\section{Note}

Note 1. This study is an extended and revised version of the oral presentation presented at the XII. International Congress on Educational Research in Rize on 25-28 April 2019.

\section{Copyrights}

Copyright for this article is retained by the author(s), with first publication rights granted to the journal.

This is an open-access article distributed under the terms and conditions of the Creative Commons Attribution license (http://creativecommons.org/licenses/by/4.0/). 